\title{
GEOMORPHOLOGIC EVOLUTION OF A COASTAL KARST: THE GULF OF OROSEI (CENTRAL-EAST SARDINIA, ITALY)
}

\author{
GEOMORFOLOŠKI RAZVOJ OBALNEGA KRASA \\ NA PRIMERU OROSEJSKEGA ZALIVA \\ NA VZHODNI OBALI SARDINIJE (ITALIJA)
}

JO DE WAELE ${ }^{1}$

${ }^{1}$ University of Cagliari, Geology Department, Via Trentino 51, 09127 Cagliari (Italy), geoam@unica.it 


\begin{abstract}
UDC: 551.44:551.468(450.88)

Jo De Waele: Geomorphologic evolution of a coastal karst: the Gulf of Orosei (central-east Sardinia, Italy)
\end{abstract}

In the past ten years cave surveying has allowed better understanding of speleogenesis in the Orosei Gulf (Central-East Sardinia, Italy), one of the most important coastal karst areas of Italy. Surface geomorphologic research has been accompanied by subterranean and submarine landform analysis in order to try and understand the evolution of this coastal karst since its emersion in Upper Eocene. The main factors influencing the geomorphic processes are lithology, tectonics, palaeo-climate and sea level changes. The study of several important cave systems demonstrates a complex geological history with karst processes that started in Early Tertiary and accelerated during Plio-Quaternary.

Key Words: geomorphology, speleology, speleogenesis, coastal karst, Gulf of Orosei, Sardinia, Italia.

\title{
Izvleček
}

UDK: 551.44:551.468(450.88)

\section{Jo De Waele: Geomorfološki razvoj obalnega krasa na primeru Orosejskega zaliva na vzhodni obali Sardinije (Italija)}

Orosejski zaliv je eno najpomembnejših obalnokraških območij v Italiji. Številne nove meritve jam so omogočile boljše razumevanje speleogeneze na območju zaliva. Razvoj krasa na tem območju smo raziskovali z različnimi geomorfološkimi raziskavami na površju in pod morjem, ter spelološkimi raziskavami v jamah. Glavni faktorji morfoloških procesov so litologija, tektonika, paleoklima in nihanja morske gladine. Študija nekaterih pomembnih jamskih sistemov je pokazala kompleksen geološki razvoj, kjer so kraški procesi igrali pomembno vlogo od zgodnjega terciarja in dosegli višek v pliokvartarju.

Ključne besede: geomorfologija, speleologija, speleogeneza, obalni kras, Orosejski zaliv, Sardinija, Italija. 


\section{INTRODUCTION}

Coastal carbonate areas are characterized by unique karst features related to the vicinity of the marine environment. In proximity of the coast the mixing of salt and fresh water causes hyperkarst phenomena that lead to typical landforms. Carbonate coasts also preserve many evidences of Quaternary sea level changes. The fluctuation of sea level has an important influence on coastal morphogenesis, with cyclic erosion and quiescent periods, and thus also guide cave development.

The Gulf of Orosei is a good example of coastal karst areas, and recent cave research combined with geomorphologic investigation has enabled to enhance the knowledge of karst evolution of this coast.

This area is located in the central-eastern part of Sardinia (Italy) and is constituted of a $37 \mathrm{~km}$ long succession of vertical limestone cliffs that reach heights up to 700 meters, stretching from the village of Cala Gonone in the North to Santa Maria Navarrese in the South (Fig. 1).

\section{GEOLOGICAL SETTING}

The Gulf of Orosei coastal karst area is characterized by a sedimentary sequence of dolomites and limestones reaching a total thickness of about 800 meters covering unconformably a Paleozoic granite or biotitic schist basement (De Waele \& Pisano 1997)(Fig. 1).

The Mesozoic transgression occurred after a long-during continental period, estimated from Permian to Lower Jurassic, occupying an undulating Variscan peneplain during Bajocian-Bathonian. The Middle Jurassic-Lower Cretaceous sea never reached great depths in the Gulf of Orosei area, and the different carbonate facies evidence several shallow depositional environments, going from lagoons to coral reefs. This sedimentary sequence is composed of dolostones containing limestone lenses, oolithic limestones and massive fossil-rich outer-shelf, reef, interreef and backreef limestones (Dieni \& Massari 1985).

The Jurassic transgression starts with clastic sediments of the Genna Selole Formation, represented by quartz conglomerates and sandstones with plant fossils typical of a fluvial or delta environment influenced by tidal movements (Amadesi et al. 1960; Fazzini et al. 1974; Dieni et al. 1983). Upwards this facies becomes marly, typical of a littoral depositional environment and the alternation of marl and dolostone beds preludes the Dorgali Formation dolostones (Amadesi et al. 1961; Calvino et al. 1972; Dieni \& Massari 1985; 1987). These dolostones are sandy in the basal levels becoming pure brownish dolostones in the upper beds and locally contain Brachiopods, Echinoids, Ammonites, Belemnites and Foraminifers of Bathonian-Callovian age (Middle Jurassic) (Dieni \& Massari 1985).

Upon these dolostones two heterotopic limestone Formations are reported: the Monte Tului and Monte Bardia Formations (Dieni \& Massari 1985).

The first is characterized by microcrystalline and oolithic sandy limestones for a varying thickness of 0-120 m deposited in an outer-shelf environment. The fossil fauna (Ammonites, Belemnites, Brachiopods, Echinoids and Foraminifers) gives an age of Callovian-Upper Kimmeridgian (MiddleUpper Jurassic). The Monte Bardia Formation instead is composed of typical reef and bioclastic limestones, with frequent fossil corals (sometimes in life position) and their debris. The age of these limestones, based on Corals, Gastropods, Algae and Foraminifers is Kimmeridgian-Berriasian (Upper Jurassic-Lower Cretaceous). 


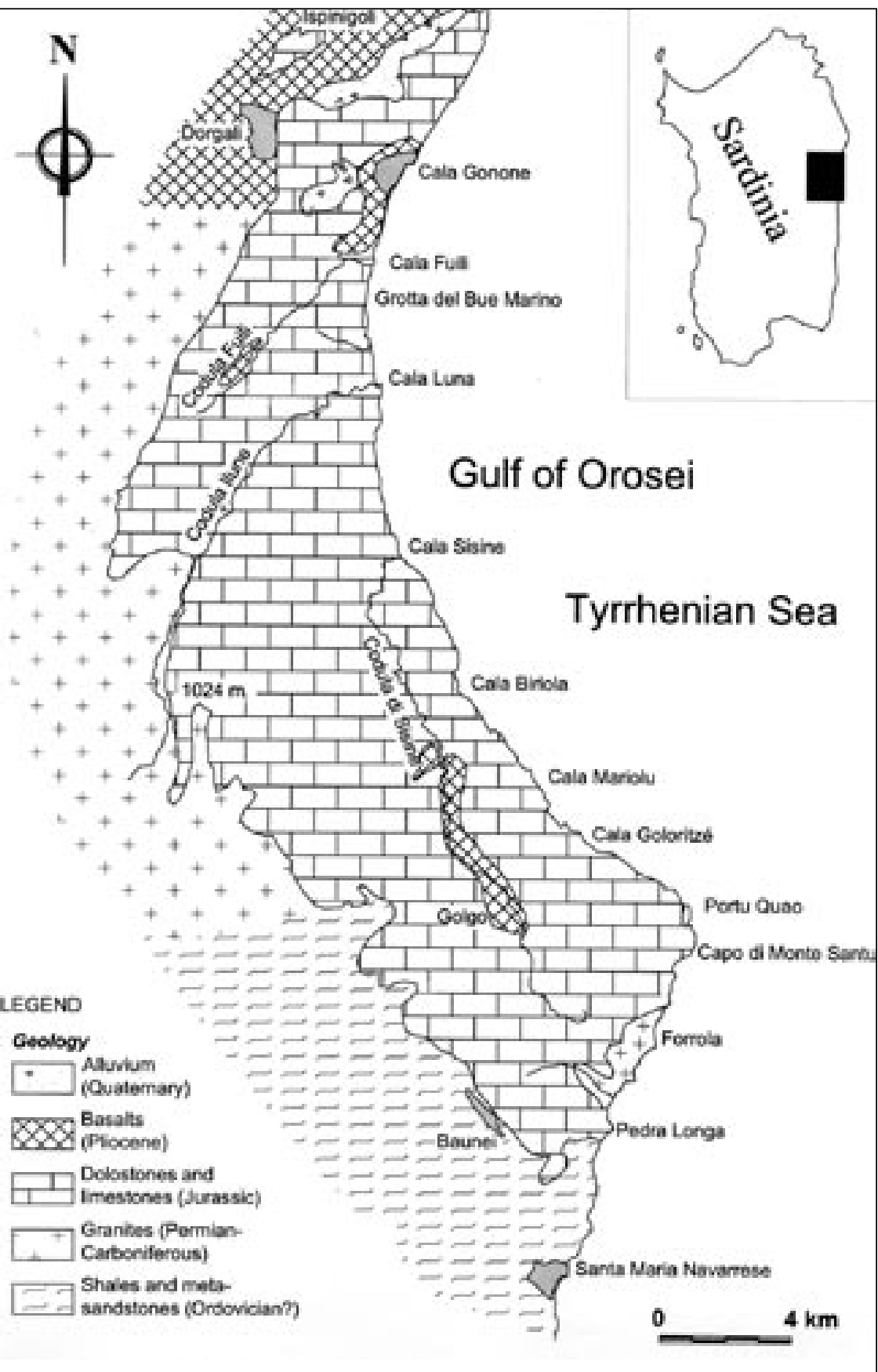

Fig. 1 - Geological sketch map of the Gulf of Orosei. 
The sea was probably continuously present in the area until Early Tertiary, even though no marine sediments of these periods have been preserved. In fact, the discovery of Maastrichtian pebbles in the post-Middle Eocene conglomerate of Cuccuru 'e Flores, outcropping in tectonically disturbed areas nearby (e.g. Monte Albo Monte Tuttavista, Supramonte), indicates that these Upper Cretaceous sediments were eroded in Early Tertiary times (Busulini et al., 1984). This syn-tectonic continental Cuccuru 'e Flores conglomerate was deposited after Middle Eocene during a tectonic instable and continental period related to the Pyrenean and Apennine collision (Dieni \& Massari, 1965).

The first sediments locally recognizable upon the Mesozoic rocks in the Gulf of Orosei are the alluvial conglomerates and quartz sands of the Nuraghe Casteddu Formation, related to an intense erosion-deposition cycle caused by an uplifting phase of Middle Pliocene age (Massari \& Dieni 1973). These sediments precede and are contemporary to the effusion of Pliocene basalts that have given K-Ar ages of $3.56 \pm 0.23$ to $1.99 \pm 0.08$ million years (Savelli \& Pasini 1973).

Upon these basalts alluvial sands and conglomerates are found (Cala Gonone, San Pietro valley, Biddunie, Cala Luna) probably deposited during Early Pleistocene (Dieni \& Massari 1966). During Pleistocene several periglacial sediments were deposited, the most interesting are the stratified slope-waste deposits (éboulis ordonnées), composed of limestone fragments in a reddish clay matrix forming coastal cliffs of more than 40 meters height and developing up to $600 \mathrm{~m}$ a.s.l., and aeolian sands visible in karst pockets, along the limestone cliffs up to several meters a.s.l. and also on the near shore continental shelf up to 40 meters b.s.l..

From a structural point of view the Jurassic carbonate cover is tilted towards the East (center of the Gulf) with an almost constant dip of $20-30^{\circ}$. This monocline structure is disturbed by two transcurrent arcuate fault systems directed NNW-SSE and NNE-SSW (Pasci 1997). Among the first the Serra Oseli fault can be mentioned with an inverse and sinistral cinematic with almost 500 meters vertical uplifting of the eastern limb. The second fault system is well represented in the Southern part of the Gulf, with the Piano d'Otzio and the San Pietro-Onamarra dextral faults with up to 400 meters uplifting of the Eastern limb. These faults are related to the continental collision between the Apulian and the South-European plates. The eastwards lowering of the Jurassic carbonates is thus compensated by this tectonic style, and the sediments outcrop continuously up to a bathymetric depth of almost 100 meters on the continental shelf (Orrù \& Ulzega 1987).

\section{SURFACE KARST LANDFORMS}

The Gulf of Orosei karst area, occupying a surface of more than 210 square $\mathrm{km}$, is a spectacular coast of high carbonate cliffs cut by some major streams, from North to South Codula Fuili, Codula Ilune and Codula Sisine, forming canyons that end in the Sea (Fig. 1).

This hydrographic network is most probably a relic of the ancient drainage pattern related to wetter (thus warmer) periods and continues also on the shelf for several kilometers up to a depth of at least 120 meters (Orrù \& Ulzega 1987), corresponding to the maximum lowstand of the Mediterranean Sea during the Last Glacial Maximum, around 22,000 years ago.

At present surface drainage is activated only after heavy rain periods, twice a year in average, and almost exclusively interests the major rivers, meaning Codula Ilune and Sisine, and only exceptionally (once every thirty years) other tributaries (Codula Fuili, Codula Goloritzé, Bacu Maore, Bacu Mudaloro etc.). This also because Codula Ilune has more than $60 \%$ of its drainage basin extended upon 
granites and Sisine drains part of the basaltic San Pietro plain. Almost all other rivers are completely comprised in the carbonate structure, characterized by well developed underground drainage.

The fluviokarstic landscape is enriched by typical karst landforms such as dolines, well developed on the dolostones close to the contact with the Paleozoic granites in locality Marghine (Fig. 2). Here a N-S directed series of more or less big dolines and semi-closed depressions makes up one of the most important absorbing areas of the Gulf where many cave systems have been explored in the

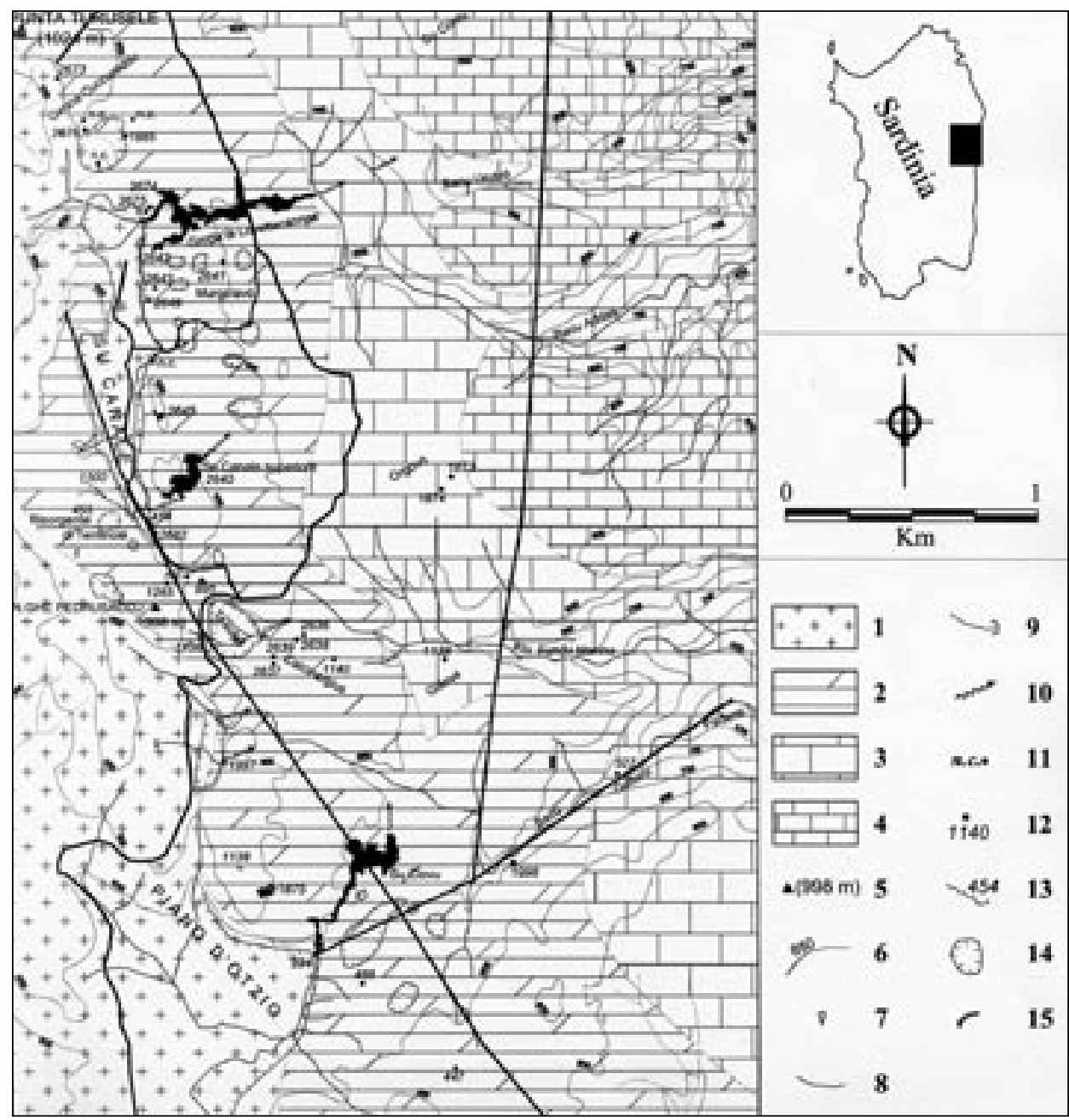

Fig. 2 - Geomorphological map of the Marghine area: PALEOZOIC: 1. Granites; MESOZOIC: 2. Dolostones (Dorgali Formation); 3. Limestones (M.te Bardia Formation); 4. Limestones (M.te Tului Formation); 5. Altimetric points; 6. contour lines; 7. springs; 8. rivers; 9. sinkholes; 10. underground drainage; 11. cave entrance (not catalogued); 12. cave entrance and cave register number; 13. cave development; 14. dolines; 15. roads. 
past few years (Brozzi et al. 1989; De Waele et al. 2002). Other karst landforms such as the rock arches, some of which attain impressive dimensions (Bacu Addas rock arch of a height and width of more than 50 meters) or are well known landmarks (Goloritzé coastal arch) are typical of the Gulf of Orosei (Barca et al. 1995).

Karst micro-morphologies are locally well developed on the massive microcrystalline limestones, with solution flutes (rillenkarren), solution pans (kamenitze) and lapiez fields.

Morphology in the coastal areas is caused by a combination of karst and littoral processes, and erosion is locally enhanced by corrosion that becomes prevalent where mixing between fresh and salt water occurs leading to hyperkarst phenomena (De Waele et al. 2001). Many erosion sea caves, formed by the wave action on joints and structurally weaker areas, are located along the coast. Where fresh water outlets occur, instead, mixing phenomena have lead to the development of important coastal karst caves reaching development of several kilometers (De Waele \& Forti 2002).

Another important coastal morphology is the tidal notch, well developed along the entire carbonate coast of the Gulf and indicating present and past mean sea levels. Such tidal notches are well described from depths of $10 \mathrm{~m}$ below sea level to heights of $10.5 \mathrm{~m}$ above sea level (Carobene 1972; 1978; Carobene \& Pasini 1982; Antonioli et al. 1999). The relict tidal notch, that has a decreasing height from North to South between 10.5 and $7.7 \mathrm{~m}$ a.s.l., is attributed to the isotopic stage $5 \mathrm{e}(125,000$ B.P.) and its continuity along the $37 \mathrm{~km}$ of limestone coast testifies a relative tectonic stability since, exception given for the slight N-S tilting (Antonioli et al. 1999). The $-10 \mathrm{~m}$ tidal notch, corresponding also to a well recognizable base level since most of the coastal caves are developed at this water depth, has been formed during a period of sea level stability occurred between isotopic stages $5 \mathrm{e}$ (125,000 years B.P.) and 2 (around 20,000 years B.P.). The aeolian sand deposits outcropping on the continental shelf up to a depth of $120 \mathrm{~m}$ b.s.l. are attributed to the same period (IS 5e-2), probably characterized by climatic pulses with frequent arid intervals (Antonioli \& Ferranti 1992). A sea level still-stand is also documented at a depth of 45-50 m b.s.l., correlated by most authors to the pre-Versilian transgression (approximately 10,000 years B.P.) (Orrù \& Ulzega 1987).

\section{UNDERGROUND KARST DEVELOPMENT}

Cave exploration has revealed much new information on underground karst development in the Gulf of Orosei in the past few years, and many Authors have reassumed this speleological information (Fercia \& Pappacoda 1991; De Waele et al. 1995; Fancello et al. 1997; De Waele et al. 2002; Schafheutle et al. 2002).

The most interesting areas are the Codula Fuili and Codula Ilune canyons, the Marghine plain and the entire coastline (Fig. 3).

Codula Fuili is the northernmost fluviokarstic canyon of the Gulf and flows in a SW-NE direction following an important strike-slip fault and ending in the Tyrrhenian Sea forming the Cala Fuili beach. Many caves have been documented along its course (Fancello et al. 1997), mostly representing remnants of well developed karst systems. The underground drainage is characterized by the important Bue Marino cave, the present outflow of the system located on the coast 500 meters South of Cala Fuili, with a development of more than $15 \mathrm{~km}$ part of which are open to public. Prehistoric anthropomorphic graffiti dated 6,000 years B.P. have been discovered in the wide entrance hall, in which the Tyrrhenian relict tidal notch at $9.5 \mathrm{~m}$ a.s.l. is easily recognizable. 
The northern branch of this cave, in fact, follows the Fuili canyon and almost reaches the Barisone doline, and is constituted of a long succession of more than 40 sumps and many dry parts for a total development of $7 \mathrm{~km}$ (Fancello et al. 1994). Maximum water depth corresponds to $33 \mathrm{~m}$ b.s.l. and the underwater conduits contain speleothems.

The Southern branch, instead, initially flows in a Southwest direction for about $3 \mathrm{~km}$ where the passage becomes submerged. This 630 meters long sump reaches 32 meters of water depth and gives access to further $2.5 \mathrm{~km}$ of cave with some other smaller sumps, eventually passing under the Codula Ilune canyon (Fancello et al. 1994). The huge pre-sump passage is characterized by important sediments prevalently composed of granites, dolostones, and limestones and has cut phreatic conduits which are completely filled with basalt (Mahler 1979), related to the Pliocene volcanic period and contemporary to the basalts outcropping in the upper parts of Cala Luna, Cala Fuili and on the San Pietro plain dated 2-3 M.y. (Savelli \& Pasini 1973).

The Codula Ilune canyon contains the biggest cave system of Sardinia, explored since the early 80 's and totaling a development of more than $42 \mathrm{~km}$. The Codula Ilune cave system, discovered in the upstream part of the canyon and partially developed on the contact granite-dolostones, is characterized by two underground rivers that meet in a subterranean lake forming a unique collector. The system has at least four different cave levels easily recognizable by the presence of abandoned phreatic cave tubes and main stream passages developed at different altitudes and likely corresponding to different climatic phases (De Waele 1997; Forti \& Rossi 1991).

The present outlet of this cave system is located 100 meters South of the Cala Luna beach, and is characterized by a narrow and rectilinear passage explored for 630 meters and with a maximum

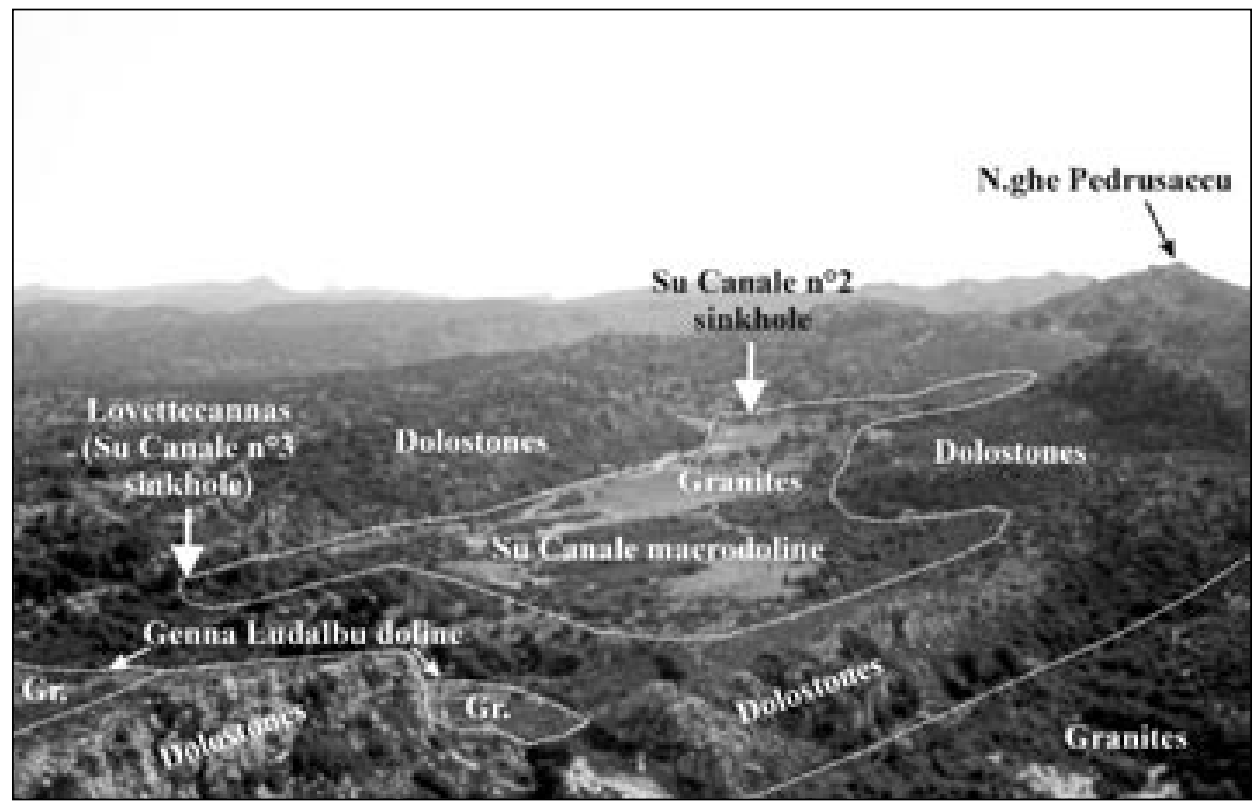

Fig. 3 - SSE Panoramic view of the Marghine-Su Canale area from Punta Turusele (1024 m a.s.l.). 
depth of $37 \mathrm{~m}$ b.s.l. but developing essentially at $10 \mathrm{~m}$ b.s.l. (Hovorka 1993). Inside this submarine karst spring remnants of aeolian cemented sediments have been found related to an arid and cold period (Antonioli \& Ferranti, 1992). Furthermore, a stalactite sampled at $9 \mathrm{~m}$ b.s.l. has given a value of $23.0 \pm 0.7$ ky B.P. (Alessio et al. 1992).

Recent explorations have discovered several interesting caves at Marghine, South of the upper Codula Ilune river at an altitude of approximately 1,000 $\mathrm{m}$ a.s.l., probably representing branches of a unique absorbing cave system that has its outlet in the Bel Torrente cave, located 500 meters North of Cala Sisine. The sinkholes of Lovettecannas, Su Canale superiore and Su Clovu develop for several kilometers along the contact between granites and dolostones (Brozzi et al. 1989; De

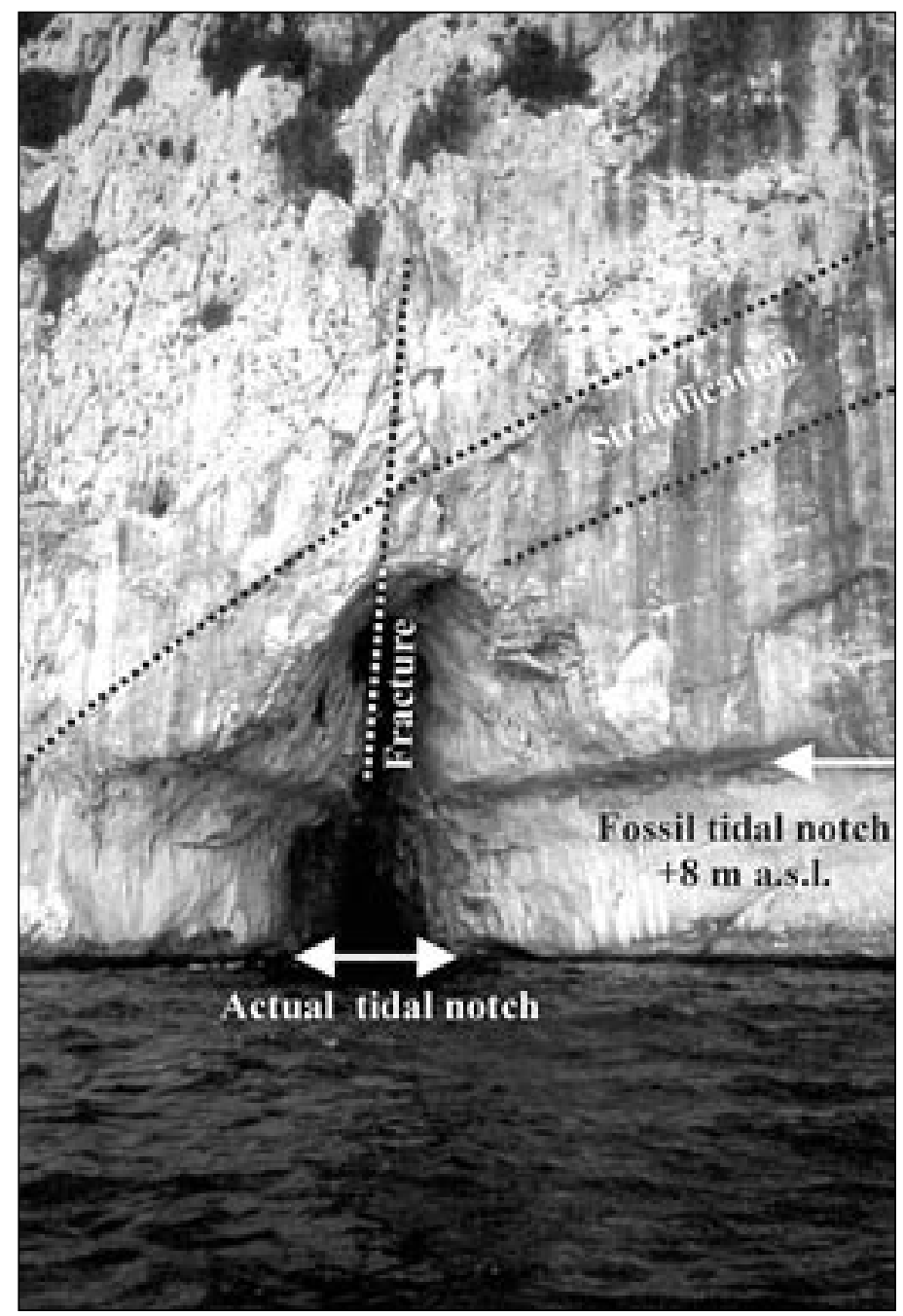

Fig. 4 - Coastal cave S of Capo di Monte Santu with clear present and fossil tidal notches. 
Waele et al. 2002) and show only scarcely formed phreatic passages, suggesting their relatively recent formation. The Bel Torrente submarine spring, instead, is a large underwater passage that develops at an average depth of $5 \mathrm{~m}$ b.s.l. and has been explored for more than 1 kilometer. The cave divides in a huge dry phreatic passage and a submerged active branch at 700 meters from the entrance, both branches are decorated with speleothems (Morlock \& Mahler 1995; Fancello et al. 2000).

Several other important caves are reported along the coast and aeolian sediments are reported both above and below sea level in many of these (Antonioli \& Ferranti 1992). The most important of these caves are the Cala Luna caves, the Fico cave and the Utopia-Ispuligidenie karst system.

Six big cave entrances are located practically at present sea level at Cala Luna and these caves, formed by hyperkarst phenomena due to mixing of sea water with meteoric water infiltrating along joints, show evidences of the high Tyrrhenian sea stand (tidal notch at $9.2 \mathrm{~m}$ a.s.l.) and an important continental phase with deposition of a thick sequence of aeolian sediments. A phreatic conduit

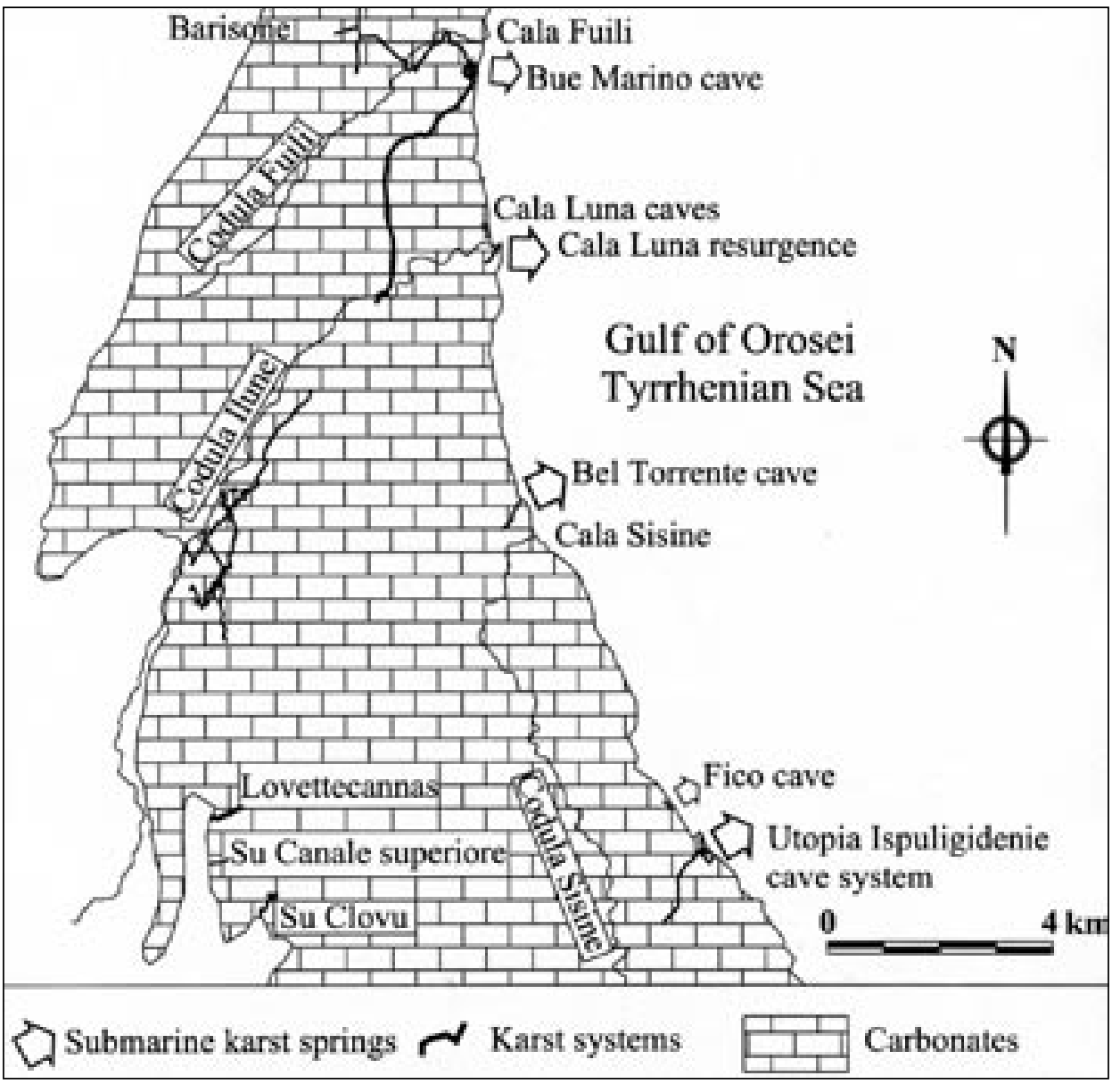

Fig. 5 - Gulf of Orosei and the most interesting caving areas. 
occupied by Pliocene basalts opens on the roof of the passage in the $6^{\text {th }}$ of these caves (Assorgia et al. 1968).

The Fico cave is located about $4 \mathrm{~km}$ South of Cala Sisine, at an altitude of $15 \mathrm{~m}$ a.s.l., and develops for more than $1 \mathrm{~km}$ (Jantschke 1998). This cave has a rather complex development with ascending branches up to almost $60 \mathrm{~m}$ a.s.l., characterized by abundant concretions (e.g. aragonite helictites), a main corridor parallel to the coastline and submerged passages up to a depth of $7 \mathrm{~m}$ b.s.l. A modest fresh water spring inside the cave is probably co-responsible of the widening of the joints by hyperkarst processes due to mixing.

The Utopia-Ispuligidenie cave system is located one more $\mathrm{km}$ to the South, in correspondence with the outlet of the Bacu Mudaloro canyon,. This system is composed of two main branches that meet close to the coastline; the active submarine karst spring of Ispuligidenie to the South and the submerged Utopia passage to the North. This impressive submarine cave system, with extremely well developed and wide cave tunnels, showing both phreatic and surface evolution, reaches a total length of $3.5 \mathrm{~km}$ representing one of the biggest underwater caves of the Mediterranean. The mean depth of the main karst tunnel is around $30 \mathrm{~m}$ b.s.l., the maximum depth is $80 \mathrm{~m}$ b.s.l. and only rarely the passage develops above sea level. Submerged speleothems have been observed to depths of $30 \mathrm{~m}$ b.s.l., representing the deepest ones found in the Eastern Sardinian coasts.

A stalactite sampled in the Organo cave, $1 \mathrm{~km}$ North of Capo di Monte Santo, has given an age of $22.4 \pm 0.7$ ky B.P. (Alessio et al. 1992).

\section{SPELEOGENESIS}

Speleogenesis in the high mountain areas (up to $1000 \mathrm{~m}$ a.s.l.) is different from the coastal one, although in both lithology and tectonics are important. The first is mainly controlled by the carbonate-noncarbonate contact and only indirectly by sea level changes while the second is by large means dependant on Quaternary eustasy causing sea level fluctuations. In fact, the Gulf of Orosei coastal karst area is characterized by an important allogenic recharge from adjacent non carbonate rocks (essentially granites). In the higher areas this allogenic drainage causes the formation of stream caves developed along the carbonate-non carbonate contact. These caves are initially formed in the transgressive sediments below the sandy dolostone beds, at the contact with the altered granites, causing the deposition of important sandy sediments. This first stage of cave development is well documented in the Marghine area (e.g. Lovettecannas, Su Canale superiore, Su Clovu), with contact stream caves in which big rooms are formed by the erosion of the tender Genna Selole Formation sediments and dry phreatic passages in dolostones are almost lacking (De Waele 2001).

The Codula Ilune cave system, instead, represents a mature form of these contact caves, also dependant on an allogenic recharge, in this case much more important (Codula Ilune). The evolution of this karst system has been influenced by the deepening of the Codula Ilune canyon, caused by Plio-Quaternary tectonic events and by sea level changes. The presence of four cave levels (active level between 75 and $15 \mathrm{~m}$ a.s.l., levels at 30, 100 and $190 \mathrm{~m}$ higher) demonstrates the succession of at least four more or less stable periods during which the base level did not change significantly permitting the development of sub-horizontal cave levels. The U/Th dating of the base and tip of a big stalagmite in the +30 level of the system has revealed its growth all through isotopic stage 5 , thus immediately following the Tyrrhenian high stand of 125,000 years B.P. (De Muro et al. 2003). 


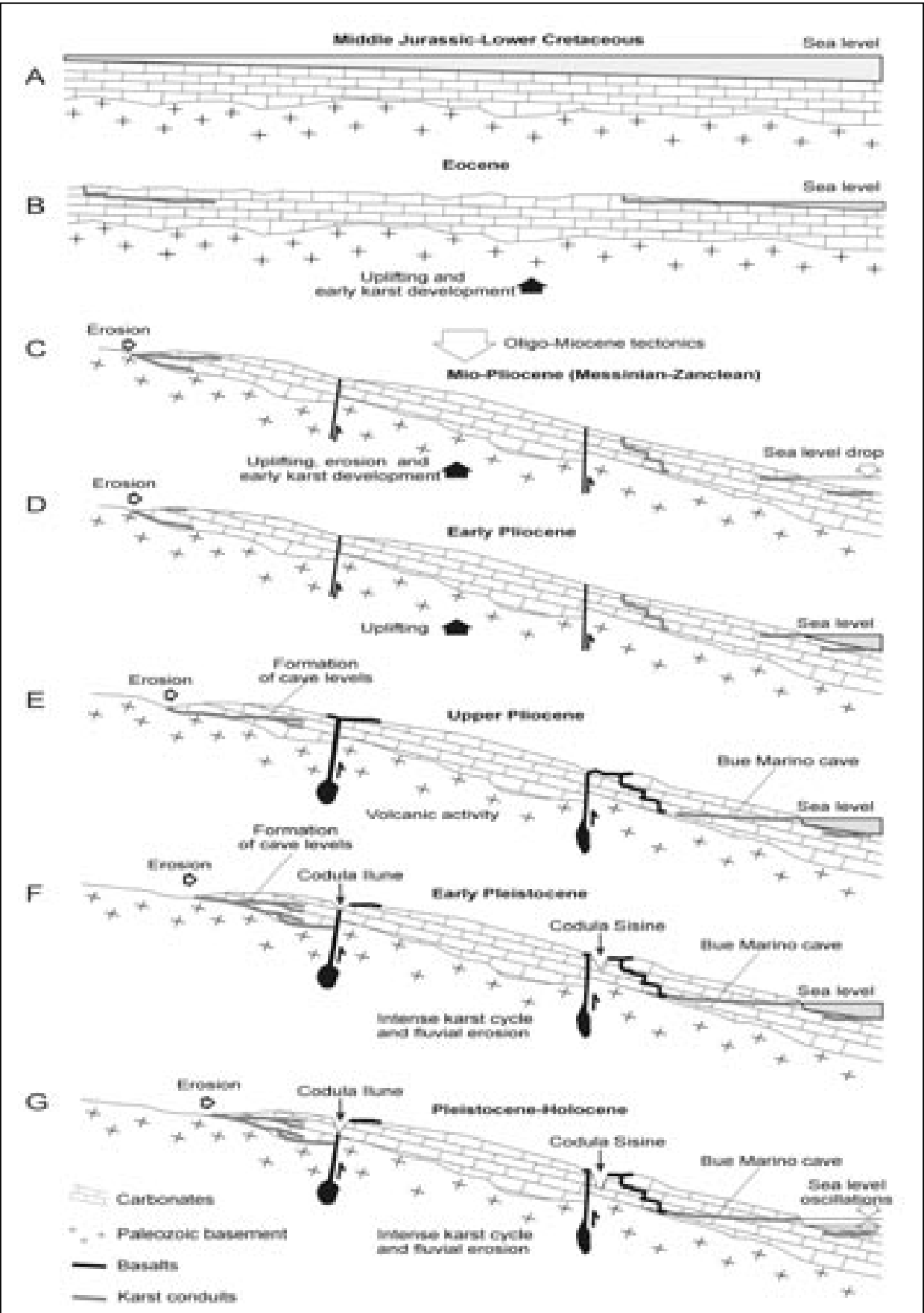

Fig. 6 - Speleogenetic hypothesis of the Gulf of Orosei karst systems. 
Cave development surely started far before the emplacement of the Pliocene basalts, as demonstrated by the infilling of well developed pressure conduits by these basalts in the Bue Marino cave (Mahler 1979). Probably the initial stages of speleogenesis can be brought back to Eocene, when the Mesozoic sediments definitely emerged and the surface erosion started. The most important karst development would have started after the Oligo-Miocene tectonic phases during which the major fault systems have determined the present structural settings of the Gulf. Karst processes have enabled the development of pressure tubes under phreatic conditions during Mio-Pliocene, and relics of this karst can be found at various altitudes and have been filled with Pliocene basalts. The sea level dropped drastically during the Messinian salinity crisis around 6.3-5.2 My B.P., caused by the closure of the Gibraltar strait and the consequent drying up of the Mediterranean (Cita \& Corselli 1993), and although the climate was semi-desertic it is generally believed that minor karst processes did occur enabling the development of phreatic tubes also at altitudes far below present sea level (Perna 1994).

Most of present day known cave development has probably been formed in the past 2 million years and is related to the lowering of the base level induced by sea level fluctuations and tectonic uplifting. In fact, the Codula Ilune canyon has deepened its course prevalently in the past 2 million years, because the basalts outcropping on top of the limestones at Fruncu Nieddu (altitude $100 \mathrm{~m}$ a.s.l.) immediately North of Cala Luna (2.26 \pm 0.08 million years) (Savelli \& Pasini 1973), have been cut by the valley. The same Pliocene basalts, also cut by the canyon, are found also at Biddunie $3 \mathrm{~km}$ Southwest, at an altitude of $300 \mathrm{~m}$ a.s.l.. This rejuvenation of the relief is the result of the uplifting of the Paleozoic basement also documented in other areas of the Island (the Flumendosa river deepened its course at least 400 meters in the past 2 million years cutting a Upper Pliocene basalt platform) (Marini \& Murru 1983).

The most intense karst forming processes probably occurred during Middle Pleistocene (between isotopic stages 9 and 6, approximately 350,000-130,000 years B.P.), during one or more wet interglacial periods, because most of the coastal caves are characterized by the presence of the Tyrrhenian tidal notch at 8-10 m a.s.l. (e.g. Bue Marino and Cala Luna caves).

Relative tectonic stability has been acquired in the Gulf since isotopic stage 5, as demonstrated by this Tyrrhenian tidal notch, well preserved along more than $50 \%$ of the carbonate coastline, evidencing a decreasing height of $10.5 \mathrm{~m}$ a.sl. in the North to $7.7 \mathrm{~m}$ a.s.l. in the South without abrupt changes in height (Antonioli et al. 1999).

The sea level has been decreasing since with several still stands, such as the one around 10-12 m b.s.l., confirmed by the development at this depth of many submarine caves. About 22,000-18,000 years B.P. the sea level retreated to $120 \mathrm{~m}$ b.s.l., enhancing cave development and causing the deposition of aeolian sediments on the coastal plain (the present continental shelf) and in the cave entrances, demonstrating that many of these caves were already existing.

Two stalactites from $5 \mathrm{~m}$ b.s.l. in the Organo cave $9 \mathrm{~m}$ b.s.l. in the Cala Luna resurgence have been dated respectively 22,499 +/- 670 e 23,050 +/- 690 years B.P. (Alessio et al. 1992). Furthermore, the depth reached by some of the submarine caves such as Utopia $(-80 \mathrm{~m})$ together with the presence of vadose morphologies demonstrates that sea level probably has been underneath this altitude for quite an important lapse of time (Schafheutle et al. 2001).

A synthesis of speleogenesis of the Gulf of Orosei karst area is represented in Fig. 4, based on the present geomorphological and speleological knowledge. 


\section{CONCLUSIONS}

The speleological and geomorphological investigation of the coastal karst features of the Gulf of Orosei has enabled to draw a preliminary speleogenetical hypothesis of this important coastal karst area. Surface, underground and submerged karst landforms show evidences of different karst episodes. Karst processes started in Eocene, since early emersion, and continued up to now in a more or less continuous way. Karst features can be positioned chronologically thanks to infillings of Pliocene basalts and Quaternary sediments and dated coastal landforms (e.g. tidal notches).

According to all available data underground karst surely developed before the Plio-Pleistocene volcanic cycle, probably starting in Eocene. The traces of this karst are very hard to find and of difficult attribution, but the regional geodynamic situation surely permitted some kind of karst evolution. Most of the ancient karst actually visible probably relates to the past 5 million years, since after the Messinian salinity crisis. The most intense and widespread karst forming processes that characterise the present morphology of the coastal karst area appear to have occurred during Middle Pleistocene (between isotopic stages 9 and 6, approximately 350,000-130,000 years B.P.), during one or more wet interglacial periods. In many coastal caves, in fact, the Tyrrhenian tidal notch is well preserved, dated approximately 125,000 years B.P. The presence of many small coastal caves at $-10 \mathrm{~m}$ b.s.l., sometimes filled with aeolian sands, may have formed during the following sea level low stands.

Although many work has still to be done, this preliminary speleogenetical hypothesis of the surface and underground karst landforms of the Gulf of Orosei, appears to explain well the geomorphologic evolution of this very eloquent coastal karst area.

\section{ACKNOWLEDGEMENTS}

I would like to thank the many colleagues, speleologists and cave divers, without whom insight in this complex coastal karst would have been much poorer. I am indebted to Ugo Sauro for his valuable comments and suggestions.

\section{REFERENCES}

Alessio, M., Allegri, L., Antonioli, F., Belluomini, G., Ferranti, L., Improta, S., Mandra, L. \& Proposito, A., 1992: Risultati preliminari relativi alla datazione di speleotemi sommersi nelle fasce costiere del Tirreno centrale.- Giornale di Geologia, 54(2), 165-193, Bologna.

Amadesi, E., Cantelli, C., Carloni, G.C. \& Rabbi, E., 1960: Ricerche geologiche sui terreni sedimentari de foglio 208-Dorgali.- Giornale di Geologia, II (28), 59-87, Bologna.

Antonioli, F. \& Ferranti, L., 1992: Geomorfologia costiera e subacquea e considerazioni paleoclimatiche sul settore compreso tra S. Maria Navarrese e Punta Goloritzé (Golfo di Orosei, Sardegna).- Giornale di Geologia, 54(2), 66-89, Bologna.

Antonioli, F., Silenzi, S., Vittori, E. \& Villani, C., 1999: Sea level changes and tectonic mobility: precise measurements in three coastlines of Italy considered stable during the last $125 \mathrm{ky}$ Physics and Chemistry of the Earth (A), 24(4), 337-342, Amsterdam.

Assorgia, A., Bentini, L. \& Dernini, C., 1968: Nuove conoscenze sulle grotte costiere del settore di Cala di Luna (Dorgali-Sardegna Orientale).- Atti Congresso Internazionale Studi Sardi, 10, 4-31, Cagliari. 
Barca, S., Di Gregorio, F. \& Mulas, G., 1995: Natural rock arches of the Orosei Gulf, Sardinia, Italy.- in Ozhan E. (ed.), Medcoast 95, 1, 217-229, Ankara.

Brozzi, G., Pumo, A., Rodolfi, G. \& Sivelli, M., 1989: L'inghiottitoio di Su Clovu.- Sottoterra 82, 26-40, Bologna.

Busulini, A., Dieni, I., Massari, F., Pejovic, D. \& Wiedmann, J., 1984: Nouvelles données sur le Crétacé supérieur de la Sardaigne orientale.- Cretaceous Research, 5, 243-258, Amsterdam.

Calvino, F., Dieni, I., Ferasin, F. \& Piccoli, G., 1972: Note illustrative della Carta Geologica d'Italia, Foglio 195-Orosei (Sardegna).- 9-39, Roma.

Carobene, L., 1972: Osservazioni sui solchi di battente attuali ed antichi nel Golfo di Orosei in Sardegna.- Bollettino della Società Geologica Italiana, 91, 583-601, Roma.

Carobene, L., 1978: Valutazione di movimenti recenti mediante ricerche morfologiche su falesie e grotte marine del Golfo di Orosei.- Memorie della Società Geologica Italiana, 19, 641-649, Roma.

Carobene, L. \& Pasini, G.C., 1982: Contributo alla conoscenza del Pleistocene superiore e dell'Olocene del Golfo di Orosei (Sardegna orientale).- Bollettino della Società Adriatica di Scienze, 64, 5-35, Trieste.

Cita, M.B. \& Corselli, C., 1993: Messiniano: vent'anni dopo.- Memorie della Società Geologica Italiana, 49, 145-164, Roma.

De Muro, S., De Waele, J., Longinelli, A. \& Iacumin, P., 2003: Holocene sea-level changes and palaeoclimatic reconstruction in Central-North Sardinia : preliminary results.- Atti del Convegno GeoSed, Alghero 28 settembre-2 ottobre 2003, p. 125-131, Sassari.

De Waele, J., 1997: Complesso sotterraneo di Codula Ilune, Sardinia, Italy.- International Caver, 20, 3-10, Swindon.

De Waele, J., 2001: Geomorfologia carsica ipogea ed epigea nella zona di Su Canale (Baunei, Sardegna centro-orientale).- in De Waele, J. (ed.), Atti del Convegno di Studio Il Carsismo e la Ricerca Speleologica in Sardegna Cagliari 23-25 novembre 2001: Anthéo, 6, 61-70, Cagliari.

De Waele, J. \& Forti, P., 2002: Estuari sotterranei.- in Cicogna, F., Nike Bianchi, C., Ferrari, G. \& Forti, P., Grotte Marine: cinquant'anni di ricerca in Italia: 91-104, Rapallo.

De Waele, J., Forti, P. \& Perna, G., 2001: Hyperkarstic phenomena in the Iglesiente mining district (SW-Sardinia).- in Cidu, R. (ed.), Water-Rock Interaction 2001, Balkema, 619-622, Lisse.

De Waele, J., Grafitti, G., Locci, C., Pisano, M. \& Spiga, R., 1995: Attuali conoscenze speleologiche nel Supramonte di Baunei.- Monografia di Anthéo, 4, 1-88, Cagliari.

De Waele, J., Onnis, C. \& Robin, Y., 2002 : Lovettecannas un an d'exploration à la cote mille.Spelunca, 88, 21-38, Editions Gap, La Ravoir.

De Waele, J. \& Pisano, M., 1997: Osservazioni geologiche, geomorfologiche ed idrogeologiche sul Supramonte di Baunei (Sardegna centro-orientale).- Rendiconti del Seminario della Facoltà di Scienze dell'Università di Cagliari, 67(1), 83-97, Bologna.

Dieni, I., Fischer, J.C., Massari, F., Salard-Cheboldaeff, M. \& Vozenin-Serra, C., 1983: La succession de Genna Selole (Baunei) dans le cadre de la paléogéographie mésojurassique de la Sardaigne orientale.- Memorie della Società Geologica Italiana, 36, 117-148, Roma.

Dieni, I. \& Massari, F., 1965: Precisazione sull'età di alcuni conglomerati affioranti presso Siniscola, Orosei e Dorgali (Sardegna orientale).- Rendiconti dell'Accademia Nazionale dei Lincei, 
Classe Scienze Fisiche Matematiche e Naturali, 40, 205-211, Roma.

Dieni, I. \& Massari, F., 1966: Il Neogene e il Quaternario nei dintorni di Orosei.- Atti della Società Italiana di Scienze Naturali e Museo Civico di Storia Naturale Milano, 15, 91-141, Milano.

Dieni, I. \& Massari, F., 1985: Mesozoic of Eastern Sardinia.- in Cherchi, A. (ed.) 19th European Micropaleontological Colloquium-Guide Book, AGIP Sardinia, 1-10 October 1985: p. 6678, Cagliari.

Dieni, I. \& Massari, F., 1987 : Le Mésozoique de la Sardaigne orientale : Groupe Français du Crétacé.- Sardinia 24-29 May 1987, 125-134, Cagliari.

Fancello, L., Fileccia, A. \& Mazzoli, M., 2000: La Grotta del Bel Torrente.- Speleologia, 43, 67-69, Città di Castello.

Fancello, L., Mahler, A. \& Benysek, L., 1994: Die Höhle Bue Marino.- Cave Diving Magazine, 6, 36-39, Trieste.

Fancello, L., Mulas, G. \& Rivolta, G.P., 1997: Le grotte del territorio dorgalese $1^{\circ}$ censimento.Sardegna Speleologica, suppl., 1-104, Cagliari.

Fazzini, P., Gasperi, G. \& Gelmini, R., 1974: Ricerche sul Verrucano - 2. Le successioni basali dei "tacchi” tra Escalaplano e Jerzu (Sardegna sud-orientale).- Bollettino della Società Geologica Italiana, 93, 221-243, Roma.

Fercia, S. \& Pappacoda, M., 1991: Codula di Luna: conoscenze attuali e prospettive.- Speleologia, 24, 35-41, Milano.

Forti, P. \& Rossi, G., 1991: Idrogeologia ed evoluzione carsica della Codula di Luna (Sardegna).Atti e Memorie della Commissione "E. Boegan”, 30, 53-79, Trieste.

Hovorka, J., 1993: Cave diving exploration on Sardegna.- Czech Speleological Society, 30, 30-36, Brno.

Jantschke, H., 1998: Forschungsbericht Sardinien 1998.- p.1-22, Kirchheim.

Mahler, A., 1979: Verkarstung der Karbonatgebiete am Golfo di Orosei (Sardinien).- Geologischer Palaeontologischer Mitteilungen Innsbruck, 7 (8-9), 1-49, Innsbruck.

Marini, A. \& Murru, M., 1983: Movimenti tettonici in Sardegna fra il Miocene superiore ed il Pleistocene.- Geografia Fisica e Dinamica Quaternaria, 6, 39-42, Genova-Pontedecimo.

Massari F. \& Dieni I., 1973: La Formazione fluvio-lacustre di Nuraghe Casteddu ed i suoi rapporti con i basalti di Orosei-Dorgali (Sardegna).- Memorie della Società Geologica Italiana, 12, 377-410, Roma.

Morlock, W. \& Mahler, A., 1995: La Grotta del Bel Torrente: la più importante risorgenza carsica del complesso calcareo del Golfo di Orosei.- Sardegna Speleologica, 8, 35-36, Cagliari.

Orrù, P. \& Ulzega, A., 1987: Rilevamento geomorfologico costiero e sottomarino applicato alla definizione delle risorse ambientali (Golfo di Orosei, Sardegna orientale).- Memorie della Società Geologica Italiana, 37, 471-479, Roma..

Pasci, S., 1997: Tertiary transcurrent tectonics of North-Central Sardinia. Bulletin de la Société Géologique de France, 168, 301-312, Paris.

Perna, G., 1994: Il carsismo profondo nel Sulcis-Iglesiente (Sardegna sud occidentale) e nel Trentino-Veneto (Alpi orientali italiane). "Carsismo Messiniano": esempi di carsismo profondo correlati con il livello del Mediterraneo nel Messiniano.- Annali dei Musei Civici di Rovereto, 10, 327-378, Rovereto. 
Savelli, C. \& Pasini, G.C., 1973: Preliminary results of K-Ar dating of basalts from Eastern Sardinia and the Gulf of Orosei.- Giornale di Geologia, 39(1), 303-312, Bologna.

Schafheutle, M., Jantschke, H., Lawo, Ph., Kühn, M. \& Kücha, A., 2001: Speleological Survey of the Baunei Coast and the Utopia Cave.- in De Waele, J. (ed.), Atti del Convegno di Studio Il Carsismo e la Ricerca Speleologica in Sardegna Cagliari 23-25 novembre 2001: Anthéo, 6, 219-226, Cagliari. 
